\title{
East-west asymmetry in long-term trends of landfast ice thickness in the Hudson Bay region, Canada
}

\author{
Alexandre S. Gagnon ${ }^{1,2, *}$, William A. Gough ${ }^{3}$ \\ ${ }^{1}$ Department of Geography, University of Liverpool, Roxby Building, Liverpool L69 7ZT, UK \\ ${ }^{2}$ Environmental Research Institute, North Highland College, UHI Millenium Institute, Thurso KW14 7JD, UK \\ ${ }^{3}$ Department of Physical and Environmental Sciences, University of Toronto at Scarborough, 1265 Military Trail, \\ Scarborough, Ontario M1C 1A4, Canada
}

\begin{abstract}
Ice cover in the Hudson Bay region (HBR) goes through a complete cryogenic cycle each year. Freeze-up typically occurs in October and November, ice cover reaches its peak thickness from late March to May, and water bodies in the HBR are usually ice-free beginning in early August. In this study, the timing and magnitude of the annual peak in ice thickness were identified for each year from weekly ice observations compiled by the Canadian Ice Service. The Mann-Kendall test was used to determine the statistical significance of the temporal trends, and their magnitude was estimated using the Theil-Sen approach. The results indicate an asymmetry in temporal trends of landfast ice thickness; statistically significant thickening of the ice cover over time was detected on the western side of Hudson Bay, while a slight thinning lacking statistical significance was observed on the eastern side. This asymmetry is related to the variability of air temperature, snow depth, and the dates of ice freeze-up and break-up. Increasing maximum ice thickness at a number of stations is correlated to earlier freeze-up due to negative temperature trends in autumn. Nevertheless, changes in maximum ice thickness were reciprocal to the variability in the amount of snow covering the ground. These results are in contrast to the projections from general circulation models (GCMs), and to the reduction in sea-ice extent and thickness observed in other regions of the Arctic. This contradiction must be addressed in regional climate change impact assessments.
\end{abstract}

KEY WORDS: Hudson Bay $\cdot$ Lake ice $\cdot$ Sea ice thickness $\cdot$ Snow depth $\cdot$ Temperature trends

Resale or republication not permitted without written consent of the publisher

\section{INTRODUCTION}

Satellite observations provide evidence of a decreasing extent in sea ice cover in the Northern Hemisphere (Maslanik et al. 1996, Cavalieri et al. 1997, Johannessen et al. 1999, Parkinson et al. 1999, Vinnikov et al. 1999, Serreze et al. 2000) and a reduction in the length of the ice season (Smith 1998, Parkinson 2000), while data from submarines indicate a decline in the thickness of the perennial ice cover over the Arctic (Rothrock et al. 1999). The Hudson Bay region (HBR), located in the marginal sea-ice zone of northern Canada, has been omitted from those studies with the exception of Parkinson et al. (1999), who found a statistically insignificant decrease in the spatial extent of sea ice over Hudson Bay in all seasons but winter.
Gagnon \& Gough (2005a) found statistically significant trends for Hudson Bay toward earlier break-up of ice in the spring and later freeze-up in the autumn during the period 1971-2003, in agreement with the projections from General Circulation Models (GCMs; Gagnon \& Gough 2005b). In addition to the dates of ice freeze-up and break-up, ice thickness data are available from the Canadian Ice Service (CIS), and they have been used in climate change studies (Brown \& Cote 1992) and for validating sea-ice models (Flato \& Brown 1996). Nevertheless, ice thickness data for Hudson Bay have not been tested for trends as an indicator of possible climate change. Sea ice is a good indicator of climate change and variability, and the Canadian ice thickness data are particularly useful for climate change monitoring, 
since they are often taken in close proximity to a weather station.

The study area was the Hudson Bay region (HBR), including Hudson Bay proper, James Bay in the south, Foxe Basin to the north, Hudson Strait to the east, as well as adjacent land areas (see Fig. 2). The HBR is covered by first-year ice. Sea-ice formation begins in northern Hudson Bay proper in late October and spreads southward in November and December (Prinsenberg 1986a). Second-year ice, i.e. ice that has survived the summer season, is found on rare occasions, but is limited to NE Hudson Bay proper (Etkin \& Ramseier 1993). Hudson Bay proper is completely covered by ice from January to May, with the exception of occasional leads (cracks or fractures) along the coast (Maxwell 1986). In June, the coastal leads become more extensive and areas of open water first appear in southern James Bay as the $0^{\circ} \mathrm{C}$ isotherm moves northward, and in NW Hudson Bay proper, because of the prevailing NW winds in the region. Areas of open water also appear in early summer along the eastern coast as the spring runoff from rivers emptying into James Bay flows northward (Markham 1986, Prinsenberg 1986a). In June and July, the NW winds push the broken ice away from the northern areas, enlarging the area of open water. As a result of this break-up pattern, sea ice lasts longest in SW Hudson Bay with some ice still remaining in that region in early August (Wang et al. 1994). In contrast to Hudson Bay proper, the ice cover of James Bay breaks up from south to north and this bay is usually ice free by the end of July (Prinsenberg 1986a).

In Foxe Basin, north of Hudson Bay, sea-ice formation begins in early October in the northeast. Although Foxe Basin is entirely ice covered by the time sea ice spreads into northern Hudson Bay in late October, there is a permanent polynya (an area of open water in sea ice) between Hall Beach and Rowley Island, because of the strong tidal currents and prevailing winds. This polynya expands in size throughout the summer as the broken ice drifts southward through Foxe Channel. Sea ice in Foxe Basin is cleared from north to south, because of the inflow of Arctic water through Fury and Hecla Strait. Foxe Basin becomes ice-free in the summer, and the last areas with ice are found off the north coast of Southampton Island (Maxwell 1986).

The ice cover is an important component of the heat budget of the HBR, as it controls the exchange of energy between the atmosphere and ocean, and therefore plays an important role on the regional climate (Rouse 1991). As an example, sea ice offsets the moderating effect that the Hudson Bay waters would otherwise have in the winter (Maxwell 1986). The heat required to melt the annual ice cover and to warm the water column to summer values mainly determines the balance of the atmospheric flux. The advection of heat in and out of Hudson Bay proper is negligible, as are all other heat contributions, so that Hudson Bay behaves essentially like a closed ocean body (Prinsenberg 1986a, Saucier \& Dionne 1998, Gough \& Allakverdova 1999). Cold Arctic water flows into Foxe Basin through Fury and Hecla Strait and then into Hudson Bay through Roes Welcome Sound, while Atlantic water enters Hudson Bay through Hudson Strait (Prinsenberg 1986a). Water circulation is cyclonic within Hudson Bay, and warmer water exits through Hudson Strait as a surface flow (Prinsenberg 1986b).

A thinner ice cover in a warmer climate would permit greater conductive heat flux from the underlying ocean to the atmosphere, thus providing a positive feedback to regional climate change (Harvey 2000). In addition, the ice cover is the largest component of the freshwater budget of Hudson Bay proper. The freshwater flux that originates from ice melting in the spring is, on average, 2.4 times greater than that of river discharge (Loucks \& Smith 1989). In view of the importance of the seasonal ice cover on the climate and oceanography of the HBR, a better understanding of sea-ice variability is essential to undertake climate change impact assessments in the region. In fact, most of the differences amongst major GCMs in their projections of temperature and precipitation for the HBR were in part caused by changes to the seasonality of the ice cover (Gagnon \& Gough, 2005b).

The objectives of this study were to (1) investigate whether or not there are first order trends in the ice thickness record of the HBR, as an indicator of a possible climate change, and (2) provide physical explanations for any trends detected.

\section{DATA AND METHODS}

\subsection{Data}

Since 1958, CIS has been collecting ice observations from freshwater and sea shore locations in proximity to weather stations in the Canadian Arctic and sub-Arctic (Canadian Ice Service: Weekly ice thickness and onice snow depth measurements for Canadian stations. Available at: http://ice-glaces.ec.gc.ca). Ice thickness is measured weekly, normally on a Friday, starting after freeze-up when it is safe for the measurer to walk on the ice, and continuing until break-up. In addition to ice thickness, snow depth is recorded at the same time. Snow depth refers to the amount of snow over the ice cover. The technique for measuring the thickness of the ice consists in drilling a $2.5 \mathrm{~cm}$ wide vertical hole in the ice and then inserting a measuring tape into it. The 
tape is attached at one end to a weight that consists of a $15 \mathrm{~cm}$ long metal rod, which moves from a vertical to a horizontal position upon reaching the bottom of the ice cover. Next, the tape is pulled upward so that the metal rod moves horizontally against the bottom of the ice cover and the ice thickness is read from the measuring tape at the surface (MB 1961-1970, AES 1971-1996).

The ice thickness measurements follow the procedures in MANICE (1989). The ice observations are taken near shore on the landfast ice cover, but over a depth of water that exceeds the annual maximum thickness (MB 1961-1970, AES 1971-1996). Landfast ice typically forms inshore of a zone of ridge ice and is fixed to the shore, so that (unlike pack ice) it does not move with the ocean circulation (AES 1992, Flato \& Brown 1996). Although observers are requested to drill new holes every week, ice thickness measurements are made as close as possible to the established sampling location, and changes in location are described in detail by CIS (MB 1961-1970, AES 1971-1996). The weekly ice thickness and snow depth data up to 2003 are available digitally from CIS and data for 1958-1994 are published in annual reports (MB 1961-1970, AES 1971-1996). This database includes ice thickness and snow depth observations from 7 sea ice and 6 lake ice measuring stations in the HBR (Table 1, see Fig. 2).

The timing and magnitude of the maximum ice thickness were obtained for each year and at every measuring station from the weekly ice observations, a methodology adopted from Brown \& Cote (1992). At Moosonee, for example, sea ice forms in early November and grows linearly throughout the winter until a maximum ice thickness of $93 \mathrm{~cm}$ is reached in late

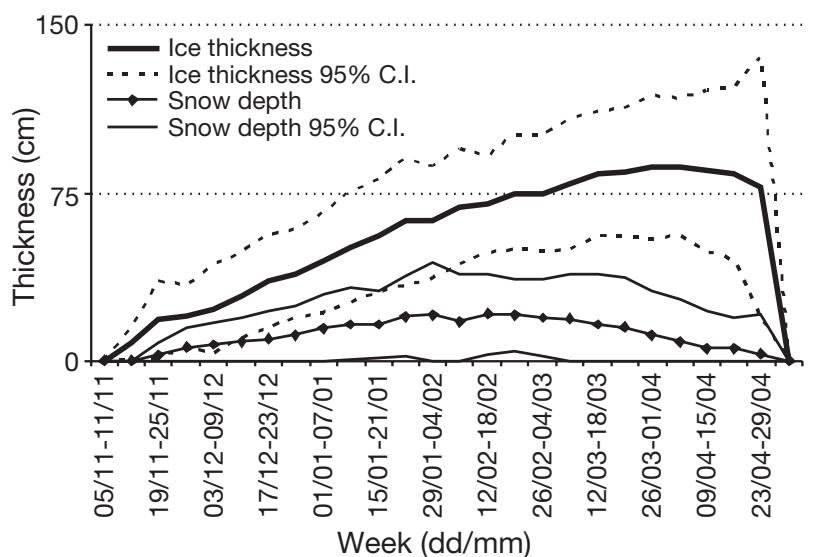

Fig. 1. Climatology (1961-1990) of weekly ice thickness and snow depth at Moosonee (Ontario) from freeze-up to break-up. C.I.: $95 \%$ confidence intervals

March (Fig. 1). Thereafter, the ice cover melts rapidly and Moosonee is completely free of ice in early May. Some time series have missing values, because ice thickness observations stopped prior to the end of the ice season or they were not consistently reported every week at the time peak ice thickness is normally attained. Quality control was conducted by comparing the change in ice thickness from one week to the next in order to identify suspicious values. The main potential sources of errors in the dataset are disturbances within the measurement area, changes in location, use of different observers within the same ice season (Brown \& Cote 1992), and typographical errors when digitising the data. For these reasons, the lengths of the time series in Table 1 do not always correspond to the duration of the ice thickness record.

Table 1. Ice thickness measuring sites in the Hudson Bay region (HBR), and duration of the data record; years with missing values excluded from 'Series length'

\begin{tabular}{|c|c|c|c|c|c|c|c|}
\hline ID & Stn & Measuring site & $\begin{array}{c}\text { Start date } \\
(\mathrm{mm} / \mathrm{dd} / \mathrm{yr})\end{array}$ & $\begin{array}{l}\text { End date } \\
(\mathrm{mm} / \mathrm{dd} / \mathrm{yr})\end{array}$ & $\begin{array}{c}\text { Series length } \\
\text { (yr) }\end{array}$ & $\begin{array}{l}\text { Latitude } \\
\left({ }^{\circ} \mathrm{N}\right)\end{array}$ & $\begin{array}{l}\text { Longitude } \\
\left({ }^{\circ} \mathrm{W}\right)\end{array}$ \\
\hline \multicolumn{8}{|c|}{ Sea ice } \\
\hline YCS & Chesterfield Inlet & Spurrell Inlet & 11/06/1959 & 01/30/1981 & 21 & 63.3 & 89.4 \\
\hline YYQ & Churchill & Churchill River & 01/12/1960 & 04/10/1987 & 19 & 58.3 & 93.8 \\
\hline YZS & Coral Harbour & South Bay & 12/05/1958 & $11 / 01 / 2003$ & 36 & 64.1 & 82.7 \\
\hline YUX & Hall Beach & Foxe Basin & 01/30/1959 & 06/01/2003 & 35 & 68.8 & 80.8 \\
\hline PHI & Inukjuak & Inukjuak River & 02/27/1959 & 06/08/1990 & 28 & 58.5 & 77.9 \\
\hline YGW & Kuujjuarapik & Great Whale River & 12/08/1972 & 04/26/1991 & 18 & 55.3 & 76.2 \\
\hline WZC & Moosonee & Moose River & 02/20/1959 & 04/23/1993 & 33 & 51.3 & 79.4 \\
\hline \multicolumn{8}{|c|}{ Lake ice } \\
\hline YBK & Baker Lake & Baker Lake & 12/05/1958 & 03/01/2003 & 34 & 64.3 & 95.9 \\
\hline WTL & Big Trout Lake & Big Trout Lake & $11 / 25 / 1960$ & 05/15/1992 & 31 & 53.8 & 88.1 \\
\hline YPI & Ennadai Lake & Ennadai Lake & 04/14/1959 & 11/30/1979 & 21 & 61.1 & 99.1 \\
\hline YIV & Island Lake & Island Lake & 01/15/1971 & 04/24/1998 & 28 & 53.9 & 93.3 \\
\hline YVP & Kuujjuak & Lake Stewart & 16/12/1972 & 05/12/1995 & 22 & 58.1 & 67.5 \\
\hline WMT & Matagami & Bell River & 12/08/1972 & 03/22/1991 & 18 & 49.7 & 79.4 \\
\hline
\end{tabular}


Ice thickness and snow depth were first measured at Baker Lake and Coral Harbour in 1958. A number of measuring sites were established in the following 2 $\mathrm{yr}_{\mathrm{r}}$ and the remaining ones in the early 1970s. Although the digital dataset extends up to 2003, a few measuring sites closed throughout the 1980s and 1990s, because of budget cuts to government agencies (Lenormand et al. 2002), so that the length of the time series varies considerably among stations. The first ice-thickness measuring site to close in the HBR was Ennadai Lake in 1979. Measurements were discontinued at 7 more stations until 1995 (Table 1). Although ice thickness was measured at Inukjuak until 1996, the location of the measuring site changed significantly in 1990 (from upstream of the river mouth to a site offshore from the town dock on Hudson Bay) and, consequently, the last 6 years were not included in the time series. All ice thickness stations in northern Canada were closed in the year 2000, but as a result of increased interest in climate change studies some stations were re-opened in autumn 2002; 3 of these stations (Baker Lake, Coral Harbour, and Hall Beach) are located in the HBR.

Freeze-up and break-up dates at the ice thickness measuring sites were obtained from the Canadian Ice Database (CID), compiled by the Meteorological Service of Canada (MSC). The number of sites where the freeze-up and break-up dates are reported has declined drastically from about 300 water bodies in the 1980 s to 12 sites during the $2000-2001$ ice season (Lenormand et al. 2002).

Seasonal air temperature data were obtained for 17 weather stations (see Fig. 2) from a homogenized dataset developed for climate change analyses at Environment Canada (Vincent 1998, Mekis \& Hogg 1999, Vincent \& Gullett 1999).

\subsection{Statistical analysis}

The non-parametric Mann-Kendall (MK) test was used to identify the presence of first order trends in the time series of maximum ice thickness (magnitude and time of occurrence), seasonal air temperature, snow depth, and the dates of ice freeze-up and break-up. The analysis of the snow depth data was more complicated than that of air temperature, because inconsistency in the reporting of snow depth at some measuring sites precluded the computation of a seasonal average. Thus, the MK test was run on the mean annual on-site snow depth at 6 measuring sites only: Baker Lake, Big Trout Lake, Inukjuak, Island Lake, Kuujjuak, and Moosonee.

The MK test (also referred to as Kendall's tau when the $x$-axis is time) determines whether trends in a time series are statistically significant or not at a selected significance level (Helsel \& Hirsch 1992); it does not require the assumption of normality and is not affected by missing values. The MK test has been widely used in a number of climatic and hydrological studies in which the statistical significance of monotonic trends was tested (e.g. Burn 1994, Lettenmaier et al. 1994, Gan 1998, Lins \& Slack 1999, Zhang et al. 2000, 2001, Gagnon \& Gough 2002). The null hypothesis for this test states that all observations are independent, whereas the alternative hypothesis signifies that a monotonic trend, positive or negative, exists in the time series. The MK test, however, does not provide an estimate of the trend magnitude, and the Theil-Sen approach (TSA), an algorithm derived by Hirsch et al. (1982), was used for this purpose. The TSA is also nonparametric and consists of the median of all possible pair-wise slopes in the dataset and consequently provides a more robust slope estimate than the leastsquare method (Sen 1968, Hirsch et al. 1982).

One requirement of the MK test is that all observations in a time series must be independent. However, most geophysical time series contain serially correlated data, as the climatic and ice conditions in one year often affect those in the subsequent year. Serial correlation must be accounted for, as it increases the sample variance and thus the probability of the test statistic to reject the null hypothesis. A time series is assumed to include 3 components, the trend, the autoregressive process (i.e. serial correlation), and the white noise (Zhang et al. 2000). To eliminate the serial correlation component, von Storch (1995) suggested that the time series be 'pre-whitened' prior to running the MK test through autoregressive and integrated moving average (ARIMA) models. This study adopted this procedure, but the time series was first detrended, since the presence of serial correlation can influence the estimate of a trend (Zhang et al. 2000, Yue et al. 2002). Moreover, the presence of a trend in a time series can result in erroneous detection of serial correlation (Yue et al. 2002), and some time series in the current study do not meet the stationary requirement of ARIMA modelling if the trend is not removed a priori.

The MK test was implemented directly on the data when no statistically significant serial correlation existed in the time series, otherwise the Yue et al. (2002) method was used prior to assessing the statistical significance of the trend. This method comprises 4 steps: (1) The slope of the sample data is estimated using the $\mathrm{TSA}_{i}$ if the slope differs from zero it is assumed to be linear and it is removed from the original time series (i.e. linearly de-trended). We do not assume that the trend in peak ice thickness is linear; nevertheless, the application of a linear trend to the 
data is simpler and commonly used in similar studies. (2) The de-trended time series is used to estimate the lag-1 autocorrelation coefficient and, if the latter is statistically significant, the time series is pre-whitened to remove the autoregressive process from it. (3) The residual time series and the linear trend are combined together. (4) The MK test is applied to the time series in order to determine whether the trend is statistically significant or not at the 0.05 and 0.10 significance levels (Yue et al. 2002).

\section{RESULTS}

\subsection{Maximum ice thickness}

Maximum sea-ice thickness was, on average, $175 \mathrm{~cm}$ in Hudson Bay, and ranged from $93 \mathrm{~cm}$ at Moosonee to $237 \mathrm{~cm}$ at Inukjuak (Table 2). Thickness increased with latitude and also from west to east, as the ice piles up on the eastern side of Hudson Bay because of the prevailing NW winds. Among the lake ice stations, Baker Lake had the thickest and Matagami (the southernmost lake) had the thinnest ice cover. Ice thickness is measured at shore locations, and it is thicker there than offshore, where it forms later. Maximum ice thickness is normally reached in late March at southern localities and in May at northern localities, with considerable interannual variation, varying from 14.3 to $27.2 \mathrm{~d}$ and from 10.1 to $19.1 \mathrm{~d}$ at the sea-ice and lake-ice measuring sites, respectively (Table 2).

The MK test revealed significant increases in maximum ice thickness over time at Big Trout Lake and Moosonee $(p<0.05)$, and at Chesterfield Inlet and Coral Harbour $(\mathrm{p}<$ 0.10) (Table 3 ; Fig. 2). The trend at Moosonee, for example, translates into an increase in ice thickness of more than $28 \mathrm{~cm}$ during the period 1959-1993 (Fig. 3). In addition, statistically significant trends towards an earlier occurrence of maximum ice thickness were detected at Coral Harbour, Hall Beach, and Kuujjuarapik. A statistically significant thinning trend was detected at Matagami. Moreover, the sign of the trends revealed that in contrast to western Hudson Bay, the ice cover has become thinner over time at Inukjuak, Kuujjuak, and Kuujjuarapik, but these trends lack statistical significance.

\subsection{Air temperature}

The MK test revealed statistically significant trends in air temperature during the period 1959-2001 in the HBR, but the trends are not temporally or spatially homogenous. Cooling trends were observed in winter in northern and NE Hudson Bay, while temperatures increased in other regions during the same season (Table 4). Warming is spatially homogenous across the HBR in both spring and summer, while autumnal temperatures also appear to be warming, with the exception of the southern HBR, where no trends are observed.

Table 2. Climatology of the freeze-up and break-up dates, maximum ice thickness and time occurrence of that maximum ice thickness in the Hudson Bay region (HBR). Dates are \pm SD in days

\begin{tabular}{|c|c|c|c|c|}
\hline Stn & $\begin{array}{l}\text { Freeze-up } \\
\text { date }\end{array}$ & $\begin{array}{c}\text { Max. ice } \\
\text { thickness }(\mathrm{cm})\end{array}$ & $\begin{array}{l}\text { Date of max. } \\
\text { ice thickness }\end{array}$ & $\begin{array}{l}\text { Break-up } \\
\text { date }\end{array}$ \\
\hline \multicolumn{5}{|l|}{ Sea ice } \\
\hline Chesterfield Inlet & Oct $29 \pm 11.1$ & $189 \pm 20.3$ & Apr $27 \pm 16.7$ & Jun $7 \pm 19.3$ \\
\hline Churchill & Oct $20 \pm 15.7$ & $174 \pm 14.3$ & Apr $25 \pm 16.0$ & May $22 \pm 17.8$ \\
\hline Coral Harbour & Oct $17 \pm 11.0$ & $180 \pm 16.7$ & May $20 \pm 16.0$ & Jun $19 \pm 15.7$ \\
\hline Hall Beach & Oct $8 \pm 11.9$ & $212 \pm 26.3$ & May $23 \pm 21.9$ & Jun $15 \pm 15.9$ \\
\hline Inukjuak & Oct $25 \pm 13.7$ & $237 \pm 26.5$ & Apr $30 \pm 17.4$ & May $19 \pm 17.3$ \\
\hline Kuujjuarapik & Nov $20 \pm 15.1$ & $140 \pm 27.2$ & Apr $10 \pm 17.4$ & May $6 \pm 11.8$ \\
\hline Moosonee & Nov $11 \pm 7.6$ & $93 \pm 16.0$ & Mar $26 \pm 13.0$ & Apr $19 \pm 12.5$ \\
\hline \multicolumn{5}{|l|}{ Lake ice } \\
\hline Baker Lake & Oct $10 \pm 9.4$ & $228 \pm 13.5$ & May $1 \pm 18.2$ & Jun $13 \pm 16.3$ \\
\hline Big Trout Lake & Oct $26 \pm 10.5$ & $115 \pm 14.7$ & Apr $13 \pm 12.0$ & May $7 \pm 13.3$ \\
\hline Ennadai Lake & Oct $16 \pm 8.7$ & $170 \pm 24.8$ & May $2 \pm 11.7$ & Jun $8 \pm 18.3$ \\
\hline Island Lake & Nov $3 \pm 9.3$ & $90 \pm 14.5$ & Mar $28 \pm 17.8$ & Apr $21 \pm 12.3$ \\
\hline Kuujjuak & Oct $28 \pm 11.1$ & $144 \pm 19.1$ & Apr $24 \pm 14.9$ & May $6 \pm 12.5$ \\
\hline Matagami & Nov $19 \pm 11.6$ & $72 \pm 10.1$ & Mar $19 \pm 20.7$ & Apr $10 \pm 10.7$ \\
\hline
\end{tabular}

Table 3. Mann-Kendall test for long-term changes in maximum ice thickness $\left(\mathrm{cm} \mathrm{yr}^{-1}\right)$ and date when maximum ice thickness is first attained $\left(\mathrm{d} \mathrm{yr}^{-1}\right)$ in the Hudson Bay region (HBR), estimated by the Theil-Sen approach; ${ }^{*} \mathrm{p}=0.90,{ }^{* *} \mathrm{p}=0.95$

\begin{tabular}{|lcccc|}
\hline \multirow{2}{*}{ Stn } & \multicolumn{2}{c}{ Max. ice thickness } & \multicolumn{2}{c|}{ Date of max. ice thickness } \\
& Regression & $\mathrm{p}$ & Regression & $\mathrm{p}$ \\
\hline Sea ice & & & & \\
Chesterfield Inlet & $1.45 \mathrm{t}+175$ & $0.099^{*}$ & $-0.35 \mathrm{t}+141$ & 0.671 \\
Churchill & $0.90 \mathrm{t}+166$ & 0.201 & $-0.50 \mathrm{t}+123$ & 0.550 \\
Coral Harbour & $0.50 \mathrm{t}+173$ & $0.070^{*}$ & $-0.40 \mathrm{t}+153$ & $0.097^{*}$ \\
Hall Beach & $0.10 \mathrm{t}+204$ & 0.770 & $-0.60 \mathrm{t}+155$ & $0.046^{* *}$ \\
Inukjuak & $-0.45 \mathrm{t}+247$ & 0.525 & $-0.15 \mathrm{t}+128$ & 0.646 \\
Kuujjuarapik & $-0.80 \mathrm{t}+145$ & 0.622 & $-2.50 \mathrm{t}+130$ & $0.003^{* *}$ \\
Moosonee & $0.82 \mathrm{t}+80$ & $0.013^{* *}$ & $0.21 \mathrm{t}+81$ & 0.333 \\
Lake ice & & & & \\
Baker Lake & $-0.30 \mathrm{t}+233$ & 0.460 & $0.10 \mathrm{t}+124$ & 0.870 \\
Big Trout Lake & $0.80 \mathrm{t}+102$ & $0.017^{* *}$ & $-0.20 \mathrm{t}+107$ & 0.548 \\
Ennadai Lake & $-0.50 \mathrm{t}+176$ & 0.504 & $-0.50 \mathrm{t}+127$ & 0.371 \\
Island Lake & $0.00 \mathrm{t}+90$ & 0.952 & $-0.60 \mathrm{t}+103$ & 0.171 \\
Kuujjuak & $-0.30 \mathrm{t}+144$ & 0.648 & $0.20 \mathrm{t}+111$ & 0.650 \\
Matagami & $-0.60 \mathrm{t}+78$ & $0.060^{*}$ & $-1.30 \mathrm{t}+88$ & 0.494 \\
\hline
\end{tabular}




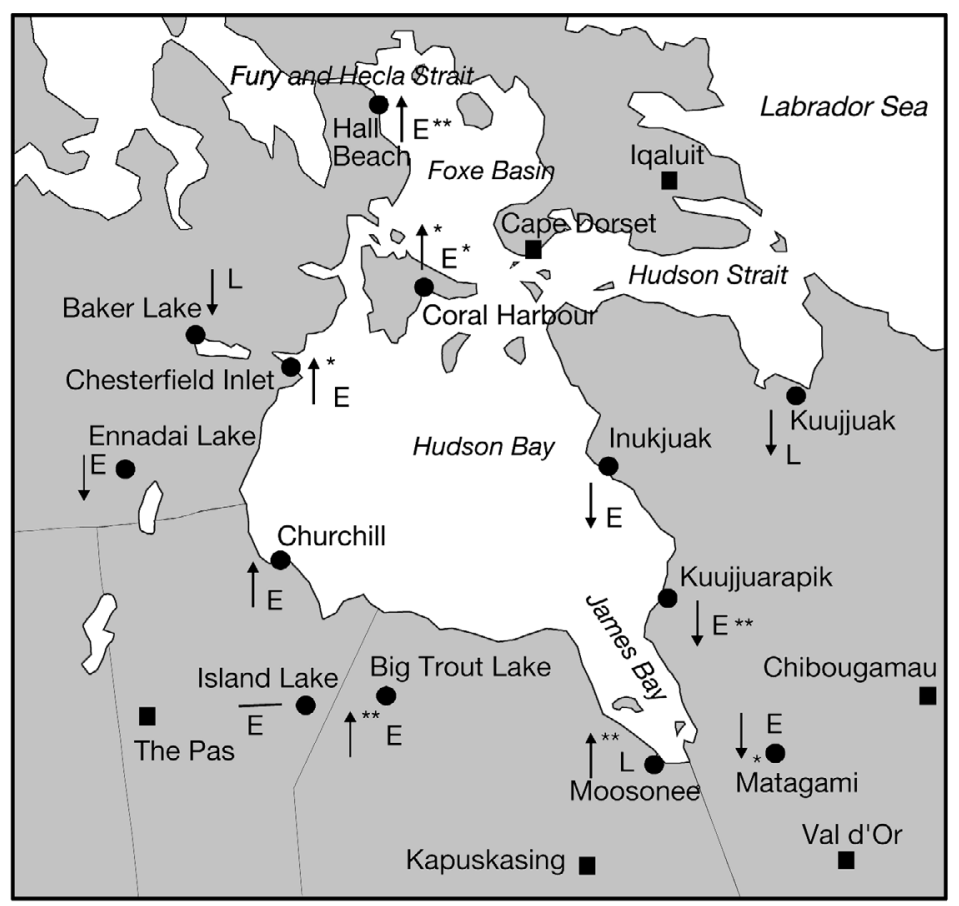

Fig. 2. Ice thickness trends in the Hudson Bay region (HBR). @: ice thickness measuring sites; $\mathbf{a}$ : weather stations. Ice thickness measuring sites have a weather station, with the exception of Island Lake and Matagami. An arrow pointing upward/downward indicates an increasing/decreasing trend in maximum ice thickness; E and L stand for earlier and later occurrence of maximum ice thickness, respectively. ${ }^{*} \mathrm{p}=0.90,{ }^{* *} \mathrm{p}=0.95$
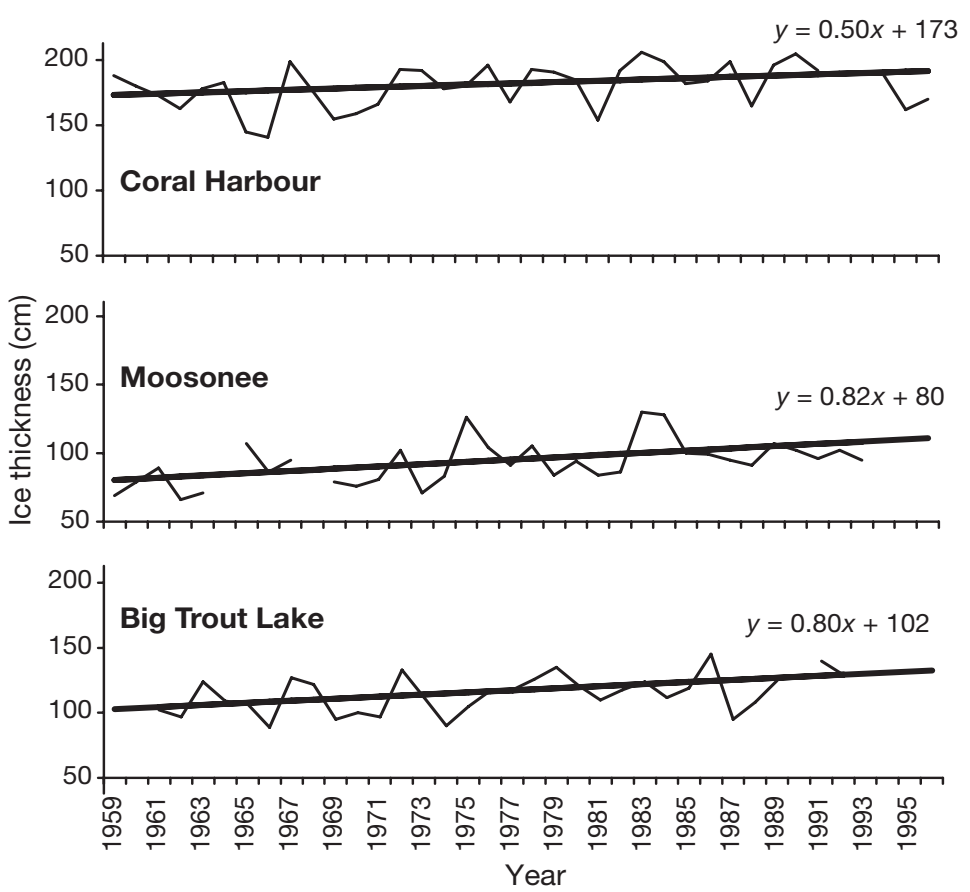

Fig. 3. Annual variation in maximum ice thickness at Coral Harbour, Moosonee, and Big Trout Lake. Bold line: linear trend obtained using the Theil-Sen approach; intercept: $\beta_{0}=y_{\text {med }}-\beta_{1} t_{\text {med, }}$, where $y_{\text {med }}$ and $t_{\text {med }}$ are medians
The increase in temperature in the HBR has not occurred in a unidirectional way. Warming peaked in the early 1950s, followed by cooling through the 1960s and into the early 1970 s, and by renewed warming thereafter. This temporal variability in the temperature record of the HBR follows quite closely that of the northern hemisphere (Maxwell 1986). Therefore, the trend pattern for the last several decades is very sensitive to the time period chosen for analysis. Since temperature trends were calculated for time periods corresponding to the ice thickness record (Table 4), different results were obtained at a number of weather stations when only the time period corresponding to that of the ice thickness measurements was analysed. In particular, the near zero trends in autumnal temperatures at Big Trout Lake and Moosonee become negative and even show statistical significance at Moosonee, where temperatures have cooled by about $1.7^{\circ} \mathrm{C}$ during the 1960-1993 period.

\subsection{Snow depth}

The MK test revealed statistically significant thinning trends in the seasonal snow pack during the period corresponding to the ice thickness measurements at Moosonee $(\mathrm{n}=$ $32, \beta=-0.16, p<0.10)$ and Big Trout Lake $(\mathrm{n}=29, \beta=-0.26, \mathrm{p}<0.05)$. Baker Lake, with a snowpack averaging only $3.7 \mathrm{~cm}$ in thickness from November through April, had the thinnest snow depth of all ice-thickness measuring sites in the HBR. Although there was inter-annual variability in snow depth at this site, no trend is observed during the period 1960-1998 ( $\beta=0.04)$. Also, no significant change in snow depth was observed at Island Lake $(\beta=-0.05)$, while seasonal snow depth at Inukjuak and Kuujjuak increased at a rate of 0.19 and $0.18 \mathrm{~cm}$ per year, respectively; these trends, however, lack statistical significance. The snow depth record at Kuujjuarapik has numerous missing values, but there is a general tendency towards a thinner snow pack in January and February with no major change in the following months. At Chesterfield Inlet, Coral Harbour, and Ennadai Lake, the trends in snow depths were negative for all months from December through April, while they were slightly positive at Hall Beach from January through April. 


\subsection{Freeze-up and break-up dates}

The MK test revealed statistically significant trends toward earlier freeze-up for time periods corresponding to those of the ice thickness measurements at Baker Lake and Chesterfield Inlet (Table 5). The sign and magnitude of the trends also indicate an earlier occurrence of freeze-up at Big Trout Lake, Coral Harbour, Kuujjuak, and Moosonee, a later freeze-up date at Churchill, Ennadai Lake and Inukjuak, and no trend at Hall Beach. Statistically significant trends towards earlier break-up were identified at Big Trout Lake, Chesterfield Inlet, Churchill, Coral Harbour, Ennadai Lake, and Hall Beach. Negative trends, representing later break-up, but lacking statistical significance, were observed at some other measuring sites.

\section{DISCUSSION AND CONCLUSIONS}

The sea-ice measuring sites located on the western sector of the HBR share a pattern with statistically significant trends toward a thicker ice cover detected at 3 of the sites. On the other hand, negative trends in maximum ice thickness, meaning a thinning of the annual ice cover, are observed in the eastern sector. This east/west asymmetry of the trends in maximum ice thickness extends over 3 of the lakes in the region. Maximum ice thickness decreased at Kuujjuak and Matagami in the eastern HBR and increased at Big Trout Lake in the western sector, but the lack of a trend at Island Lake and the thinning trends at Baker Lake and Ennadai Lake, also situated west of Hudson Bay, are opposite to this regional dichotomy. Furthermore there was a general tendency toward earlier occurrence of peak ice thickness at the majority of the sites, with statistically significant trends at Hall Beach and Kuujjuarapik.

The thickening of the ice cover in the western sector of the HBR is associated with negative trends in autumn temperatures at Big Trout Lake, Chesterfield Inlet, Churchill and Moosonee for coinciding time periods, but not at Coral Harbour where the increase in maximum ice thickness was statistically significant even though autumn temperatures did not decrease at this site. The thinning trends in peak ice thickness at Inukjuak and Kuujjuak are associated with a lack of negative trends in autumn temperatures, but the ice cover also became thinner over time at Kuujjuarapik even though a negative temperature trend was observed in autumn at this station. The thinning trends at Baker Lake and Ennadai Lake, located west of Hudson Bay, are opposite to those recorded at Big Trout Lake and at the sea-ice measuring sites in the region, but cooling temperatures have not occurred in the autumn at those 2 sites.

Previous studies have indicated that the climate of the HBR is mainly controlled by air temperature variations, and that temperature anomalies play a dominant role in inter-annual variability of ice cover in the HBR (Wang et al. 1994, Mysak et al. 1996). Thus, a question that arises is whether the cooling trends in autumn in western Hudson Bay have contributed to earlier seaice formation and, consequently, a thickening of the

Table 4. Mann-Kendall test for long-term change in seasonal temperatures in the Hudson Bay region (HBR), estimated by the Theil-Sen approach; ${ }^{*} p=0.90,{ }^{* *} p=0.95$

\begin{tabular}{|c|c|c|c|c|c|c|c|c|c|c|}
\hline \multirow[t]{2}{*}{ Stn } & \multirow[t]{2}{*}{ Period } & \multicolumn{4}{|c|}{ Temperature $\left({ }^{\circ} \mathrm{C}\right.$ decade $\left.{ }^{-1}\right)$} & \multirow[t]{2}{*}{ Period } & \multicolumn{4}{|c|}{ Temperature $\left({ }^{\circ} \mathrm{C}\right.$ decade $\left.{ }^{-1}\right)$} \\
\hline & & Winter & Spring & Summer & Autumn & & Winter & Spring & Summer & Autumn \\
\hline \multicolumn{11}{|l|}{ Sea ice } \\
\hline Chesterfield Inlet & $1960-1980$ & -0.03 & $1.04^{*}$ & 0.10 & -0.16 & $1959-2001$ & 0.14 & $0.67^{* *}$ & $0.57^{* *}$ & 0.33 \\
\hline Churchill & 1961-1986 & 0.36 & $1.00^{* *}$ & -0.11 & -0.31 & 1959-2001 & 0.36 & $0.64^{* *}$ & $0.42^{* *}$ & 0.17 \\
\hline Coral Harbour & $1959-1996$ & $-0.53^{*}$ & 0.17 & 0.20 & 0.13 & $1959-2001$ & -0.27 & $0.45^{* *}$ & $0.33^{* *}$ & 0.30 \\
\hline Hall Beach & 1959-1999 & -0.29 & $0.52^{* *}$ & 0.22 & $0.53^{* *}$ & $1959-2001$ & -0.13 & $0.61^{* *}$ & $0.25^{*}$ & $0.53^{* *}$ \\
\hline Inukjuak & $1959-1990$ & -0.33 & 0.20 & 0.15 & -0.02 & 1959-2001 & -0.06 & 0.35 & $0.60^{* *}$ & 0.21 \\
\hline Kuujjuarapik & $1973-1991$ & -0.15 & 0.20 & -0.43 & -0.18 & 1959-2001 & 0.29 & 0.39 & $0.50^{* *}$ & 0.23 \\
\hline Moosonee & $1960-1993$ & 0.14 & $0.44^{*}$ & 0.27 & $-0.50^{*}$ & $1959-2001$ & $0.53^{* *}$ & $0.55^{* *}$ & $0.42^{* *}$ & 0.00 \\
\hline \multicolumn{11}{|l|}{ Lake Ice } \\
\hline Baker Lake & 1959-1998 & 0.13 & $0.65^{* *}$ & $0.55^{* *}$ & 0.28 & 1959-2001 & 0.38 & $0.83^{* *}$ & $0.50^{* *}$ & 0.36 \\
\hline Big Trout Lake & 1961-1992 & 0.61 & $0.87^{* *}$ & 0.26 & -0.47 & 1959-2001 & $0.59^{*}$ & $0.84^{* *}$ & 0.14 & 0.00 \\
\hline Ennadai Lake & $1959-1979$ & 0.04 & $1.58^{*}$ & -0.08 & 0.42 & & & & & \\
\hline Kuujjuak & 1973-1995 & $-1.78^{*}$ & -0.22 & 0.00 & 0.20 & $1959-2001$ & -0.33 & $0.53^{* *}$ & $0.32^{* *}$ & 0.20 \\
\hline \multicolumn{11}{|c|}{ Meteorological stations without ice data } \\
\hline Cape Dorset & & & & & & $1959-2001$ & 0.00 & $0.47^{* *}$ & $0.38^{* *}$ & 0.19 \\
\hline Chibougamau & & & & & & 1959-2001 & $0.82^{* *}$ & $0.55^{* *}$ & $0.39^{* *}$ & 0.11 \\
\hline Iqaluit & & & & & & $1959-2001$ & -0.55 & 0.20 & 0.16 & 0.15 \\
\hline Kapuskasing & & & & & & $1959-2001$ & $0.47^{* *}$ & $0.46^{* *}$ & $0.30^{* *}$ & 0.05 \\
\hline The Pas & & & & & & 1959-2001 & $0.82^{* *}$ & $0.74^{* *}$ & 0.12 & 0.17 \\
\hline Val d'Or & & & & & & 1959-2001 & 0.27 & $0.32^{*}$ & 0.21 & -0.03 \\
\hline
\end{tabular}


Table 5. Mann-Kendall test on freeze-up and break-up dates; nd: not determined (freeze-up dates reported inconsistently); ${ }^{* *} \mathrm{p}=0.95$

\begin{tabular}{|lcccc|}
\hline Stn & Period & $\begin{array}{c}\text { Freeze-up } \\
\text { date }\end{array}$ & Period & $\begin{array}{c}\text { Break-up } \\
\text { date }\end{array}$ \\
\hline Sea ice & & & & \\
Chesterfield Inlet & $1960-1980$ & $-1.18^{* *}$ & $1960-1980$ & $-2.40^{* *}$ \\
Churchill & $1961-1986$ & 0.28 & $1961-1986$ & $-1.67^{* *}$ \\
Coral Harbour & $1959-1989$ & -0.30 & $1959-1988$ & $-1.07^{* *}$ \\
Hall Beach & $1960-1994$ & 0.00 & $1959-1998$ & $-0.50^{* *}$ \\
Inukjuak & $1959-1990$ & 0.28 & $1959-1990$ & -0.53 \\
Kuujjuarapik & nd & nd & $1973-1991$ & -0.19 \\
Moosonee & $1959-1993$ & -0.11 & $1959-1993$ & -0.33 \\
& & & & \\
Lake ice & & & & \\
Baker Lake & $1959-1990$ & $-0.46 * *$ & $1959-1990$ & -0.11 \\
Big Trout Lake & $1961-1992$ & -0.29 & $1961-1992$ & $-0.76^{* *}$ \\
Ennadai Lake & $1959-1979$ & 0.33 & $1959-1979$ & $-2.35^{* *}$ \\
Island Lake & nd & nd & $1971-1998$ & 0.00 \\
Kuujjuak & $1973-1995$ & -0.36 & $1973-1995$ & 0.17 \\
\hline
\end{tabular}

ice cover, since it would have more time to grow. The freeze-up and break-up dates are very sensitive to changes in air temperatures (Palecki \& Barry 1986, Anderson et al. 1996, Magnuson et al. 2000). In fact, the cooling temperatures in the autumn at Big Trout Lake, Chesterfield Inlet, and Moosonee coincide with an earlier occurrence of freeze-up. Although temperatures for September through December have cooled at Churchill, these negative temperature trends are not reflected in the time occurrence of freeze-up at this station. The sign of the trend at Coral Harbour indicates an earlier occurrence of freeze-up at this locality, and is opposite to the trend in autumn temperatures. Nevertheless, the freeze-up trend was computed for the period 1959-1989, and does not include the warm temperature anomalies of the last decade, which were included in the computation of the autumn temperature trend. In a similar way, there is a trend toward earlier freeze-up at Baker Lake up to 1990, but the cooling trend in autumn temperatures becomes nil when calculated through 1998, a time period corresponding to that of the ice thickness measurements.

The positive trends in spring temperatures that prevail over much of the HBR are reflected in the break-up date. Only at Kuujjuak have spring temperatures decreased, and accordingly a trend toward later break-up exists at this station. This cooling trend observed in the NE HBR is in agreement with permafrost cooling in the region (Allard et al. 1995). The statistical significance of the trends toward earlier break-up in the western side HBR is surprising given the observed increase in maximum ice thickness, as a thicker ice cover would be expected to take more time to melt.

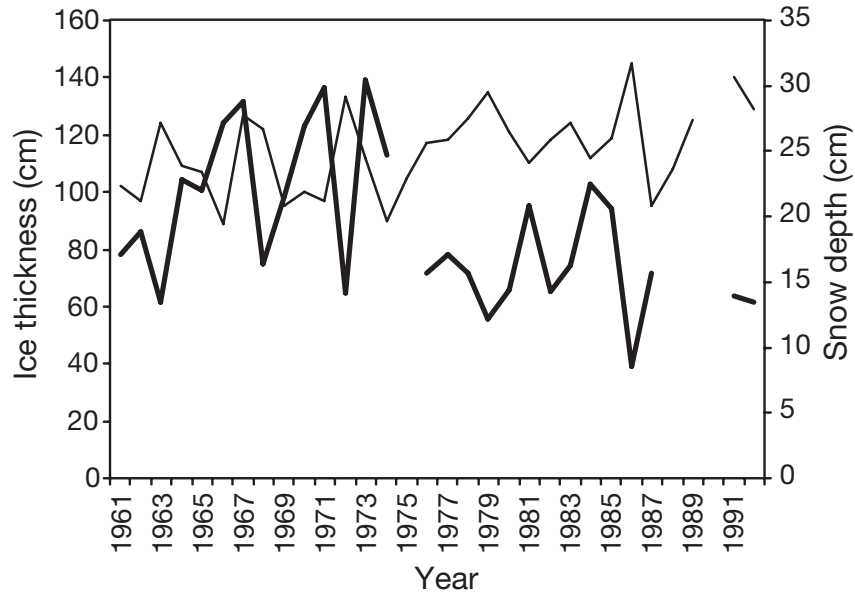

Fig. 4. Maximum ice thickness (thin line) and average annual snow depth (thick line) at Big Trout Lake

Since some exceptions were noted in the relationship proposed between freeze-up due to negative temperature trends in the autumn and increasing maximum ice thickness, another variable must therefore contribute to the variability in the landfast ice thickness of the HBR. The sensitivity of ice thickness to snow depth is well documented (Jacobs et al. 1975, Brown \& Cote 1992, Flato \& Brown 1996). Winters with high snow accumulation are associated with low ice thickness, because the snow cover insulates the ice surface, reducing heat conduction and thereby ice growth (Flato \& Brown 1998). Gough et al. (2004) analysed the relationship between ice thickness with air temperature and snow depth in the HBR and found that at the majority of the measuring sites, snow depth is a more important contributor to the inter-annual variability of the landfast ice thickness than winter air temperatures, a result that agrees with the work of Flato \& Brown (1996) on the Canadian High Arctic.

The increase in maximum ice thickness in the western HBR is consistent with a decrease in seasonal snow depth at all measuring sites. For example, there is strong and significant negative correlation between seasonal snow depth and maximum ice thickness at Big Trout Lake ( $\mathrm{r}=-0.64)$ (Fig. 4). At Inukjuak, Kuujjuak and Matagami a thicker snow pack is associated with thinning of the ice cover, while there are no trends for snow depth and maximum ice thickness at Island Lake. Maximum ice thickness decreased at Baker Lake, even though no change in snow depth was reported. The variability of ice thickness at Baker Lake, however, is likely to be more affected by variations in air temperature than in snow depth, given the shallowness of its snow pack.

Salinity conditions also influence ice cover, because of their influence on the freezing point as well as 
the thickness of the mixed layer. If river discharge increases as a result of increased precipitation, as Gagnon \& Gough (2002) observed in the NW HBR, it can be associated with positive trends in sea-ice thickness, as a year with large runoff increases the freezing temperature of the water and creates a fresher surface mixed layer that will turn more easily into ice in the subsequent autumn (Manak \& Mysak 1989). However, the fact that a lake site exhibited the same response as the sea-ice measuring sites for similar time periods provides evidence that the observed increase in maximum ice thickness along the western coast of Hudson Bay is not the result of changes in salinity or ocean heat flux.

Under-ice heat fluxes from seawater entering through Hudson Strait could not contribute significantly to the variability of the Hudson Bay ice thickness. Jones \& Anderson (1994) identified the water masses of Hudson Bay based on observations near Southampton Island and found that the deepest water mass in Hudson Bay originates from Foxe Basin and is influenced by Arctic inflow and the formation and melting of the ice cover in that area. Oceanic water also enters at depth through Hudson Strait and forms an intermediate layer isolated from the surface, so that the surface waters of Hudson Bay are mainly influenced by air temperature and freshwater variations (Jones \& Anderson 1994). Moreover, the correlation between break-up of sea ice in the HBR and spring temperatures (Etkin 1991, Gagnon \& Gough 2005a) along with the modelling work of Gough \& Allakhverdova (1999), Gough (2001), and Gagnon \& Gough (2005b) suggest that the interchange of heat with the ocean plays a minor role on the variability of Hudson Bay ice cover.

The ice observations used in this study are point observations. Nevertheless, the identification of trends that are spatially homogenous between stations, as well as the physical mechanisms suggested to explain those trends, provides evidence of the robustness of our results. Moreover, these ice thickness data are the only ones that are currently available in the HBR. The present study improves our understanding of the variability of ice cover in the HBR, which was to date limited to changes in freeze-up and break-up dates. The strong dependence of ice thickness on snow depth suggests that it is more difficult to identify an early climate change signal using fast ice data than it is using freeze-up/break-up dates. Since the results of this study are in contrast to the reduction in sea-ice extent and thickness observed in other regions of the Arctic, continued monitoring of the landfast ice thickness in the HBR is needed to determine if the east/west asymmetry in the trends of maximum ice thickness continue into the future. Nevertheless, such a monitoring study will require more than the 3 measuring sites currently remaining in the region, necessitating the reopening of several measuring sites.
Finally, a follow-up modelling study is proposed to examine in more detail the temporal and spatial variability of ice thickness in the HBR. The data analysed in this study could be used to calibrate an ice growth model. This model could be used to provide time series with a consistent time period at all measuring sites, which would be suitable for a temporal and spatial analysis, e.g. using principal component analysis.

Acknowledgements. This work was conducted with financial support from the Natural Sciences and Engineering Research Council of Canada (NSERC), the Government of Ontario/ William G. Dean Graduate Scholarship in Science and Technology, and the D. F. Putnam Graduate Scholarship. We thank L. Vincent for providing the FORTRAN code used for computing the Theil-Sen slope estimate. Also, our regards to $\mathrm{M}$. MacLeod, who informed us of the availability of the more recent ice thickness data from the Canadian Ice Service and to R. Chagnon who provided us with those data. We also acknowledge E. Demou for her help with the quality control procedure. The comments and suggestions by D. Etkin are greatly appreciated.

\section{LITERATURE CITED}

AES (Atmospheric Environment Service) (1971-1996). Ice thickness data for selected Canadian stations, freeze-up 1970 - break-up 1994. Annu Rep ICE 1-79 to 1-94, Department of the Environment, Toronto

AES (Atmospheric Environment Service) (1992) Ice thickness climatology 1961-1990 normals. Annu Rep ICE 2-91, Department of the Environment, Ottawa

Allard M, Wang B, Pilon JA (1995) Recent cooling along the southern shore of Hudson Strait, Quebec, Canada, documented from permafrost temperature measurements. Arct Alp Res 27:157-166

Anderson WL, Robertson DM, Magnuson JJ (1996) Evidence of recent warming and El Niño-related variations in ice break-up of Wisconsin lakes. Limnol Oceanogr 41:815-821

Brown RD, Cote P (1992) Interannual variability of landfast ice thickness in the Canadian High Arctic, 1950-89. Arctic 45:273-284

Burn DH (1994) Hydrologic effects of climatic change in westcentral Canada. J Hydrol 160:53-70

Cavalieri DJ, Gloersen P, Parkinson CL, Comiso JC, Zwally HJ (1997) Observed hemispheric asymmetry in global sea ice changes. Science 278:1104-1106

Etkin DA (1991) Break-up in Hudson Bay: its sensitivity to air temperatures and implications for climate warming. Climatol Bull 25:21-34

Etkin DA, Ramseier RO (1993) A comparison of conventional and passive microwave sea-ice datasets for Hudson Bay. Atmos Ocean 31:359-378

Flato GM, Brown RD (1996) Variability and climate sensitivity of landfast Arctic sea ice. J Geophys Res 101:25767-25777

Gagnon AS, Gough WA (2002) Hydro-climatic trends in the Hudson Bay region, Canada. Can Water Resour J 27: $245-262$

Gagnon AS, Gough WA (2005a) Trends and variability in the dates of ice freeze-up and break-up over Hudson Bay and James Bay. Arctic 58:370-382

Gagnon AS, Gough WA (2005b) Climate change scenarios for 
the Hudson Bay region: an intermodel comparison. Clim Change 69:269-297

Gan TY (1998) Hydroclimatic trends and possible climatic warming in the Canadian Prairies. Water Resour Res 34: 3009-3015

Gough WA (2001) Model tuning and its impact on modelled climate change response: Hudson Bay sea ice, a case study. Can Geogr 45:300-305

Gough WA, Allakhverdova T (1999) Limitations of using a coarse resolution model to assess the impact of climate change on sea ice in Hudson Bay. Can Geogr 43:415-422

Gough WA, Gagnon AS, Lau HP (2004) Interannual variability of Hudson Bay ice thickness. Polar Geogr 28:222-238

Harvey LDD (2000) Global warming: the hard science. Prentice Hall, Harlow

Helsel DR, Hirsch RM (1992) Statistical methods in water resources. Elsevier, Amsterdam

Hirsch RM, Slack JR, Smith RA (1982) Techniques of trend analysis for monthly water quality data. Water Resour Res 18:107-121

Jacobs JD, Barry RG, Weaver RL (1975) Fast ice characteristics, with special reference to the eastern Canadian Arctic. Polar Rec 17:521-536

Johannessen OM, Shalina EV, Mikes MW (1999) Satellite evidence for an Arctic sea-ice cover in transformation. Science 286:1937-1940

Jones EP, Anderson LG (1994) Northern Hudson Bay and Foxe Basin: water masses, circulation and productivity. Atmos Ocean 32:361-374

Lenormand F, Duguay CR, Gauthier R (2002) Development of a historical ice database for the study of climate change in Canada. Hydrol Process 16:3707-3722

Lettenmaier DP, Wood EF, Wallis JR (1994) Hydroclimatological trends in the continental United States, 1948-88. J Clim 7:586-606

Lins HF, Slack JR (1999) Streamflow trends in the United States. Geophys Res Lett 26:227-230

Loucks RH, Smith RE (1989) Hudson Bay and Ungava Bay icemelt cycles for the periods 1963-1983. Can Contract Rep Hydrogr Ocean Sci No. 34 Bedford Institute of Oceanography, Dartmouth, NS

Magnuson JJ, Robertson DM, Benson DJ, Wynne RH and 10 others (2000) Historical trends in lake and river ice cover in the Northern Hemisphere. Science 289:1743-1746

Manak DK, Mysak LA (1989) On the relationship between Arctic sea-ice anomalies and fluctuations in northern Canadian air temperature and river discharge. Atmos Ocean 27:682-691

MANICE (1989) Manual of standard procedures for observing and reporting ice conditions. Atmospheric Environment Service (Environment Canada), Downsview

Markham WE (1986) The ice cover. In: Martini IP (ed) Canadian inland seas. Elsevier, Amsterdam, p 101-116

Maslanik JA, Serreze MC, Barry RG (1996) Recent decreases in Arctic summer ice cover and linkages to atmospheric circulation anomalies. Geophys Res Lett 23:1677-1680

Maxwell JB (1986) A climate overview of the Canadian inland seas. In: Martini IP (ed) Canadian inland seas. Elsevier, Amsterdam, p 79-99

MB (Meteorological Branch) (1961-1970) Ice thickness data for selected Canadian stations, freeze-up 1958 - break-up 1970. Annu Rep ICE 1-5 to 1-70, Department of Transport, Toronto

Editorial responsibility: Daniel J. Leathers,

Newark, Delaware, USA
Mekis É, Hogg WD (1999) Rehabilitation and analysis of Canadian daily precipitation time series. Atmos Ocean $37: 53-85$

Mysak LA, Ingram RG, Wang J, van der Baaren A (1996) The anomalous sea-ice extent in Hudson Bay, Baffin Bay and the Labrador Sea during three simultaneous NAO and ENSO episodes. Atmos Ocean 34:313-343

Palecki MA, Barry RG (1986) Freeze-up and break-up of lakes as an index of temperature changes during the transition seasons: a case study for Finland. J Clim Appl Meteorol 25:893-902

Parkinson CL (2000) Variability of Arctic sea ice. The view from space, an 18-year record. Arctic 53:341-358

Parkinson CL, Cavalieri DJ, Gloersen P, Zwally J, Comiso JC (1999) Arctic sea ice extent, areas, and trends, 1978-1996. J Geophys Res 104:20837-20856

Prinsenberg SJ (1986a) Salinity and temperature distributions of Hudson Bay and James Bay. In: Martini IP (ed) Canadian inland seas. Elsevier, Amsterdam, p 163-186

Prinsenberg SJ (1986b) The circulation pattern and current structure of Hudson Bay. In: Martini IP (ed) Canadian inland seas. Elsevier, Amsterdam, p 187-204

Rothrock DA, Yu Y, Maykut GA (1999) Thinning of the Arctic sea-ice cover. Geophys Res Lett 26:3469-3472

Rouse WR (1991) Impacts of Hudson Bay on the terrestrial climate of the Hudson Bay lowlands. Arct Alp Res 23:24-30

Saucier FJ, Dionne J (1998) A 3-D coupled ice-ocean model applied to Hudson Bay, Canada: The seasonal cycle and time-dependent climate response to atmospheric forcing and runoff. J Geophys Res 103:27689-27705

Sen PK (1968) Estimates of the regression coefficient based on Kendall's tau. J Am Stat Assoc 63:1379-1389

Serreze MC, Walsh JE, Chapin FS III, Osterkamp T and 6 others (2000) Observational evidence of recent change in the northern high latitude environment. Clim Change 46: 159-207

Smith DM (1998) Recent increase in the length of the melt season of perennial Arctic sea ice. Geophys Res Lett 25: 655-658

Vincent LA (1998) A technique for the identification of inhomogeneities in Canadian temperature series. J Clim 11:1094-1104

Vincent LA, Gullett DW (1999) Canadian historical and homogeneous temperature datasets for climate change analyses. Int J Climatol 19:1375-1388

Vinnikov KY, Robock A, Stouffer RJ, Walsh JE and 5 others (1999) Global warming and Northern Hemisphere sea ice extent. Science 286:1934-1937

von Storch H (1995) Misuses of statistical analysis in climate research. In: von Storch $\mathrm{H}$, Navarra A (eds) Analysis of climate variability: applications of statistical techniques. Springer-Verlag, Berlin, p 11-26

Wang J, Mysak LA, Ingram RG (1994) Internannual variability of sea-ice cover in Hudson Bay, Baffin Bay and the Labrador Sea. Atmos Ocean 32:421-447

Yue S, Pilon P, Phinney B, Cavadias G (2002) The influence of autocorrelation on the ability to detect trend in hydrological series. Hydrol Process 16:1807-1829

Zhang X, Harvey KD, Hogg WD, Yuzyk TR (2001) Trends in Canadian streamflow. Water Resour Res 37:987-998

Zhang X, Vincent LA, Hogg WD, Niitsoo A (2000) Temperature and precipitation trends in Canada during the 20th century. Atmos Ocean 38:395-429

Submitted: April 18, 2006; Accepted: July 27, 2006

Proofs received from author(s): September 13, 2006 